\title{
Using Computers in Teaching in Higher Education
}

\section{Olivera Iskrenovic-Momcilovic}

University of Novi Sad, Faculty of Education, Podgoricka 4, Sombor, Serbia

Doi: 10.2478/mjss-2018-0116

\begin{abstract}
This paper describes advantages of using computers in teaching, but also problems that occur, as well as possibilities for their elimination. The main goal of the research is the formation of images which show the use of computers in higher education. The paper presents the results of a survey conducted among students of the Faculty of Education in Sombor (Serbia) about the use of computers in teaching. A sample of 126 respondents comprises students of the last year of all study programs. The results show that students and professors have a positive attitude about using computers in education and knowledge dissemination through computers. Most of them think that teachers have mastered basic computer knowledge, but give priority to teachers who know how to work with a computer, as well as to younger teachers. Students believe that many barriers occur during the use of computers, among which the most important is the inaccessibility of technical equipment. All barriers can be overcome through useful and practical computer seminars.
\end{abstract}

Keywords: computer, students, teachers, teaching, education

\section{Introduction}

The computer is the main characteristic of our time. An example cannot be found where the computer is not used because it is impossible to find a sphere of society that wholly or partially does not depend on computers. This is due to low prices of hardware and a wide array of commercial customer applications, which are used in various fields. Another reason for the massive use of computers is the emergence and development of the Internet, which allows the instantaneous exchange of information between people around the world. Availability of computers, fast flow of information and promotion of information and communication technology have led to qualitative changes in many aspects of modern society. There is an expansion of the application of computers in education (Norris, 2015). Basic characteristics of modern education are a large flow of information, availability of literature and learning (Kafyulilo et al., 2015).

Young people are exposed to a variety of multimedia contents, which are found at every step: on the computer, on the Internet, on television... In such an environment, it is necessary to improve and innovate teaching of students - to make it more acceptable, more interesting and useful. Main creators of teaching, teachers, need to develop their work in accordance with new information and communication technologies. Improving the quality of teaching is a tendency that is increasingly present in today's education (MacGregor, 2007). One of the ways to improve teaching is precisely the use of computers (Alemu, 2015). The use of computers in teaching is widespread at faculties in higher education. For such kind of teaching significant investments are needed, teacher training, but also motivation for both students and teachers. One of the main obstacles to this kind of teaching is computer prejudice.

Today, there are divided opinions on the use of computers in teaching (Hasselbring \& Glaser, 2000). Some teachers believe that computers should be introduced as soon as possible, even in the 
first year, regardless of the curriculum in question. Computers offer great opportunities for students to broaden their knowledge and horizons. Today's students accept work on the computer with incredible ease starting with the simplest of activities - the use of ready-made software, to the most complex the creation of new user applications. On the other hand, there are the advocates of the view that computers should not be introduced into teaching. According to them, this way students lose their skills and routine problem solving, they labor less in finding solutions and troubleshooting which only comes down to copying results obtained by computer. In such circumstances, teachers evaluate only the result, not the process of solving the problem, which is certainly not good.

Both of these two ways of thinking have their advantages and disadvantages, or, the ultimate goal is not to determine which is better and more correct opinion, but primarily to improve the quality of teaching and the quality of student learning (Marcial \& Rama, 2015). This imposes a logical conclusion that professors are those who should determine whether the computer is an optimal means that will help students master the material. Tall (Tall, 2000) believes that the human brain is limited in its ability to store and transfer complex information, but this limited amount of data can be processed and stored. One way that can reduce the effect of these limitations is using computers in teaching.

The traditional way of teaching leads to a maximum load of thought and intellectual abilities, but some activities take place automatically, and the knowledge is acquired in a short time. The computer provides many ways to determine the current and expand already existing knowledge. It can help students to test and increase their mental ability. First of all, the computer allows students to focus on other aspects, which are important in the development of cognitive skills, which is not possible in traditional teaching (Glusac, 2008; Suzic, 2009).

A prerequisite for the use of computers is computer literacy, which is an individual's ability to understand and apply the benefits of communications and information technology. There are several levels of knowledge and skills:

- knowledge of computer hardware and software,

- practical use of computers,

- text processing,

- working with databases,

- knowledge of various forms of communication

The way in which teachers and students use computers is important for improving the quality of knowledge. Classrooms are generally equipped with computers and projectors. Teacher lessons are unthinkable without the use of computers (Radenković \& Ivković, 1998). The computer provides an opportunity for the creation of multimedia presentations and even specialized applications for specific thematic areas of the course content. Of course, teachers' approaches differ. They decide whether to allow students to use presentations and scripts in a digital format, enabling students to pay more attention to oral presentations of teachers instead of writing down notes. The use of presentations is not just a replacement for chalks and boards, but also for teachers and students.

Creating presentations is an art in itself; the simplest are pure text, while more complex include multimedia and interaction. If standard computer equipment or equipment that provides multimedia is used, the effects of such teaching are much higher than in traditional teaching. Through multimedia presentations, information is more exciting and appealing to students. Lessons are more tailored to the needs and interests of students, and they actively participate in the process of teaching. In this way, it increases the motivation of students.

Today, one should not forget possibilities of global communication across the world's largest computer network - the Internet. It allows for the application of modern teaching at faculties with the help of computers. The faculty website is also often used and represents an important tool, which allows a teacher to monitor important information about a faculty, sets tests results and exams, teaching materials and any other information relevant to a teaching subject. E-mail reduces needs for consultations, and a student is more often in communication with teachers.

The last, but important variable in this case is a student. Textbooks and teacher lessons are no longer the only source of information for students (Mandic, \& Ristic, 2006). Today, students receive information from two sources, from professors and with the help of computers. They engage in self- 
learning and become responsible for their knowledge. In all this, the Internet is an additional resource that students can use in the computer classroom at a specific time or in their spare time. It allows students to collect information independently; they independently analyze and come to the knowledge which is no longer simple reproduction. This knowledge can be easier to apply in practice, and in this way increases the durability of knowledge, and, therefore, the motivation of students.

\section{Methods}

Making teaching more easy and efficient must inevitably lead to changes and development of teaching aids, forms and methods of teaching. Traditional teaching is characterized by verbal and work passivity of students and domination of a teacher as a source of knowledge. The main disadvantage of such teaching is one-way communication between students and teachers. Modern teaching involves the use of computers, which will overcome all shortcomings of traditional teaching. The computer will enable professors to adapt courses to the prior knowledge, interests, and abilities of students.

The subject of research is the use of computers in education, with special emphasis on its advantages and disadvantages, as well as the possibility of eliminating all the problems. Using of computers, and especially the use and implementation of educational software is essential for learning and practicing modern concepts and technologies by young people.

The main objective of the research is the formation of the image on using computers in teaching in higher education. The idea of research is to determine the importance of using computers as an additional teaching tool for faculty teachers.

Research questions are:

1. What is the availability of computer equipment at the faculty?

2. How old are professors who prefer using computers in teaching?

3. Which are study program where teachers mostly use computers in teaching?

4. What purpose do professors use computers in teaching for?

5. What are the benefits of using computers in teaching?

6. What are the barriers to using computers in teaching?

7. How to improve the use of computers in teaching?

The general hypothesis of this research is:

Hypothesis $\mathrm{H}$ : Use of computers is necessary for teaching.

From this general hypothesis, sub-hypotheses have been obtained:

Sub-hypothesis $\mathrm{H} 1$ : Teachers have a positive attitude about using computers in teaching.

Sub-hypothesis H2: Young teachers increasingly use computers in teaching.

Sub-hypothesis H3: Teachers of technical subjects use computers in teaching more than teachers of social subjects.

Sub-hypothesis H4: The use of computers in teaching has a positive effect on increasing motivation and interest of students for a subject.

Sub-hypothesis H5: The use of computers in teaching depends on technical equipment of educational institutions.

To test the proposed hypothesis and sub-hypotheses, in accordance with the research, the process of the research was conducted using an anonymous survey. The population consists of all students from all four years, and all four study programs of undergraduate studies at the Faculty of Education in Sombor (Serbia): Graduated Teacher, Graduated Preschool Teacher, Graduated Media Designer in Education and Graduated Librarian - informatician. However, only students of the last years of the studies of mentioned programs are included in the survey, as they have a complete picture of the application of computers in education. Students of other years are not involved in the research because there is not a glass clear picture of what is supposed to be teaching. The survey was conducted on 126 students of the fourth year, all four study programs. The sample is representative and given the size of the sample; some generalizations are possible within the population which has been studied.

The research involves the collection of data to answer the research questions and test the hypotheses on the present situation of problems. Seven research questions were raised to guide 
the research and six hypotheses were formulated which was tested at 0.05 level of significance. The instrument used was a questionnaire comprising four items which were designed using the five-point Likert scale of measurement. The format of a typical five-level Likert item is:

1 - strongly disagree, 2 - disagree, 3 - undecided, 4 - agree, 5-strongly agree.

The data collected were analyzed using mean and standard deviation for research questions, and the decision rule of acceptance level is anything from 2.50 and above, while the rejection level is anything below 2.50 .

\section{Results}

\subsection{Research Question 1: What is the availability of computer equipment at the faculty?}

Table 1 results showed that out of four items on computer equipment at the faculty, students agreed on three items 1, 2 and 3 which had their decision mean above 2.50 but disagreed on the item 4 which had its decision mean below 2.50. According to the Table 1, it can be concluded that students agreed on all the items except the one that professors and students have adequate information-communication technology equipment. This table also shows that the cumulative average mean of students' responses is 2.96 .

Table 1. Availability of computer equipment at the faculty

\begin{tabular}{|l|c|c|c|}
\hline \multirow{2}{*}{ Items } & \multicolumn{3}{|c|}{ Students Responses } \\
\cline { 2 - 5 } & $\bar{X}$ & SD & Decision \\
\hline There are enough computers & 3.84 & 1.40 & agreed \\
\hline There are sufficient user applications & 2.54 & 1.42 & agreed \\
\hline The Internet is available to all users & 3.59 & 1.55 & agreed \\
\hline Printing, scanning, and copying of documents possible & 1.90 & 1.25 & disagreed \\
\hline
\end{tabular}

\subsection{Research Question 2: How old are professors who prefer using computers in teaching?}

Table 2 results indicated that out of four items on the age structure of professors, items 1 and 2 had their mean scores above the decision rule of 2.50. This indicates that students feel that professors who are between 30 and 50 years old often use computers in teaching. However, items 3 and 4 equally obtained mean ratings below 2.50 showing that students disagree that professors over 50 years of age use computers in teaching. These results confirm the sub-hypothesis $\mathrm{H} 2$. It should be noted that the opinion of students is that there is no age structure of teachers who do not use computers in teaching. This table also shows that the cumulative average mean of students' responses is 2.71 , which confirms the sub-hypothesis $\mathrm{H} 1$.

Table 2. Age structure of professors who use computers in teaching

\begin{tabular}{|l|c|c|c|}
\hline \multirow{2}{*}{ Items } & \multicolumn{3}{|c|}{ Students Response } \\
\cline { 2 - 4 } & $\bar{X}$ & SD & Decision \\
\hline Between 30 and 40 years & 3.45 & 1.37 & agreed \\
\hline Between 40 and 50 years & 3.31 & 1.40 & agreed \\
\hline Between 30 and 40 years & 1.90 & 1.29 & disagreed \\
\hline More than 60 years & 1.50 & 1.10 & disagreed \\
\hline
\end{tabular}

3.3 Research Question 3: Which are study program where teachers mostly use computers in teaching?

Table 3 indicated that out of four items on study programs which use computers in teaching students disagreed on the items 1, 2 and 4, but agreed on item 3. From the table 3, it can be concluded that professors of the study program Graduated Media Designer in Education mostly use computers in 
teaching. The largest number of subjects in the study program Graduated Media Designer in Education is from technical sciences, specifically in IT. All this confirms the sub-hypothesis H3. This table also shows that the cumulative average mean of students' responses is 2.27 .

Table 3. Study programs which use computers in teaching

\begin{tabular}{|l|c|c|c|}
\hline \multirow{2}{*}{ Items } & \multicolumn{3}{|c|}{ Students Response } \\
\cline { 2 - 4 } & $\bar{X}$ & SD & Decision \\
\hline Graduated Teacher & 1.75 & 1.11 & disagreed \\
\hline Graduated Preschool Teacher & 1.71 & 1.20 & disagreed \\
\hline Graduated Media Designer in Education & 3.72 & 1.08 & agreed \\
\hline Graduated Librarian - Informatician & 1.90 & 1.29 & disagreed \\
\hline
\end{tabular}

\subsection{Research Question 4: What purpose do professors use computers in teaching for?}

Table 4 results showed that out of four items on the use of computers in teaching, students agreed on all four items which had their decision mean above 2.50. From Table 4 it can be concluded that computers are used in teaching in many ways, but mostly for displaying PowerPoint presentations and educational software. This table also shows that the cumulative average mean of students' responses is 3 .

Table 4. The use of computers in teaching

\begin{tabular}{|l|c|c|c|}
\hline \multirow{2}{*}{ Items } & \multicolumn{3}{|c|}{ Students Response } \\
\cline { 2 - 4 } & $\bar{X}$ & SD & Decision \\
\hline Displaying PowerPoint presentations & 4.78 & 1.76 & agreed \\
\hline Displaying and using educational software & 3.10 & 1.17 & agreed \\
\hline Displaying content from the Internet & 4.25 & 1.51 & agreed \\
\hline Displaying films and video clips & 2.75 & 1.30 & agreed \\
\hline
\end{tabular}

\subsection{Research Question 5: What are the benefits of using computers in teaching?}

Table 5 results showed that out of four items on benefits of using computers in teaching, students agreed on all four items which had their decision mean above 2.50 . From Table 5 it can be concluded that using computers in teaching has many good features. This table also shows that the cumulative average mean of students' responses is 3.55 , which confirms the set sub-hypothesis $\mathrm{H} 4$ and hypothesis $\mathrm{H}$.

Table 5. Benefits of using computers in teaching

\begin{tabular}{|l|c|c|c|}
\hline \multirow{2}{*}{ Items } & \multicolumn{3}{|c|}{ Students Response } \\
\cline { 2 - 4 } & $\bar{X}$ & SD & Decision \\
\hline Lessons are boring; students can be very active & 4.85 & 1.71 & agreed \\
\hline Develops independence in students & 3.50 & 1.21 & agreed \\
\hline Computer perform routine activities and leave more time for meaningful activities & 3.20 & 1.15 & agreed \\
\hline Simulation experiments which are inaccessible for economic or health reasons & 2.65 & 1.16 & agreed \\
\hline
\end{tabular}

\subsection{Research Question 6: What are the barriers to using computers in teaching?}

Table 6 results showed that out of four items on barriers in using to computers in teaching, students agreed on items 1, 2 and 3 which had their decision mean above 2.50 but disagreed on the item 4 which had its decision mean below 2.50. From Table 6 it can be concluded that the English language is not a barrier to the use of computers in teaching. The most significant problem in teaching using computers is the lack of hardware (computers, printers, monitors, scanners) and software (programs for processing text, images or sounds and other user programs), as evidenced by the sub-hypothesis $\mathrm{H} 5$. This table shows that the cumulative average mean of students' responses is 3.16 . 
Table 6. Barriers to using of computers in teaching

\begin{tabular}{|l|c|c|c|}
\hline \multirow{2}{*}{ Items } & \multicolumn{3}{|c|}{ Students Response } \\
\cline { 2 - 4 } & $\bar{X}$ & SD & Decision \\
\hline English is too present & 2.35 & 1.10 & disagreed \\
\hline Lack of hardware (computers, printers, monitors, scanners, ...) & 4.15 & 1.65 & agreed \\
\hline $\begin{array}{l}\text { Lack of software (programs for processing text, image or sound, } \\
\text { and other user programs) }\end{array}$ & 3.25 & 1.40 & agreed \\
\hline Lack of skills and time for curriculum content & 2.90 & 1.30 & agreed \\
\hline
\end{tabular}

\subsection{Research Question 7: How to improve the use of computers in teaching?}

Table 7 results showed that out of four items on options to improve using computers in teaching, students agreed on all four items which had their decision mean above 2.50. From Table 7 it can be concluded that barriers to using computers in teaching can be overcome with little effort. This table shows that the cumulative average mean of students' responses is 3.15 .

Table 7. Options to improve using computers in education

\begin{tabular}{|l|c|c|c|}
\hline \multirow{2}{*}{ Items } & \multicolumn{3}{|c|}{ Students Response } \\
\cline { 2 - 4 } & $\bar{X}$ & SD & Decision \\
\hline Better knowledge of the English language & 2.70 & 1.20 & agreed \\
\hline Increasing the number of hardware and software packages & 3.15 & 1.46 & agreed \\
\hline Increasing the number of Internet connections & 2.90 & 1.30 & agreed \\
\hline Increasing the number of useful and practical courses and seminars on computers & 3.70 & 1.54 & agreed \\
\hline
\end{tabular}

\section{Discussion}

The research involves student surveys through seven questions and proving one hypothesis and five sub-hypotheses on the use of computers in teaching. Results on Research question 1 demonstrate that the opinions of students about equipment at the Faculty of Education are mostly positive, although there is room for improvement. The Faculty is equipped with enough equipment, regardless of the difficult financial situation in the country. Students think they have enough computers and the Internet which is available to all users. However, there are no user applications, because licensed applications are expensive. The most significant problem is still printing, scanning and copying documents, because there is no sufficient number of printers, scanners, and copiers for students. They use this equipment in the Student Service Center which is a problem for them because they cannot print or copy documents at any time.

This research is about the relationship between teachers, students, and computers, and what kind of relationship this should be. The first thing we notice is that no student said that teachers do not use computers in teaching. Students think that younger teachers (in their early thirties and forties) are more motivated to use computers in teaching and to do so more often than older colleagues. Regarding the study programs, teachers at the study program Graduated Media Designer in Education mostly use computers in teaching. This is logical because of the highest number of cases in this study program are from the field of information technology. On the other hand, these teachers are graduates from technical and mathematical sciences, but they still acquired basic computer knowledge during the training.

Teachers use computers to create PowerPoint presentations mostly. PowerPoint program allows teachers to create interactive presentations that include text, images, animations, audio and video elements. The reasons for its popularity are numerous, but the most important ones are: accessibility for everyone who uses a computer, easy to use, keeps the attention of students and allows them to get involved in creating a presentation to show what they have learned (Brock \& Joglekar, 2011). The way to create a good presentation implies a good knowledge of PowerPoint, but also a response to the level of visual creativity (Inoue-Smith, 2016). Although PowerPoint program offers an extensive 
range of options (e.g., visual and audio effects) during the preparation of a presentation, it should be noted that the appearance of a presentation should not distract from the content.

A large number of teachers use information from the Internet. The Internet has become an inexhaustible source of information to both teachers and students. Students have noted that teachers use computers less to run educational software, movies, and video clips. Educational software is expensive and requires a higher level of knowledge of computer performance. Creating movies and video clips is more difficult than creating PowerPoint presentations.

Advantages of using computers in teaching are varied (Lucido \& Borabo, 1997). Lectures are no longer boring as students are active during their realization (Joy \& Srihari, 2015). Computers increase autonomy and motivation in students. They perform routine activities, so students have more time for other activities. The use of computers in a classroom allows simulations of experiments which are inaccessible for economic or health reasons.

The success of using computers in teaching depends on many barriers. Ertmer (Ertmer, 1999) classified barriers as falling into two primary categories:

- extrinsic barriers - lack of resources, inadequate training, insufficient technical support and lack of time

- intrinsic barriers - teachers'/instructors' beliefs, visions concerning technology integration, and views about teaching, learning, and knowledge.

Ertmer, Ottenbreit-Leftwich and York (Ertmer, Ottenbreit-Leftwich \& York, 2006-2007) also classified barriers, as either extrinsic or intrinsic. For instance, access to hardware, quality software, the Internet, and technical, administrative, and peer support might be viewed as extrinsic enablers, whereas personal beliefs, previous success with technology, and self-efficacy might be viewed as intrinsic enablers.

In the summarized results, it can be seen what present barriers to using computers in teaching are. The most important of them is the lack of hardware (computers, printers, monitors, scanners) and the lack of skills and time to develop instructional content. Software is also missing, as well as the knowledge of the English language. Knowledge of the English language is probably a problem with older professors because they did not learn English during education, but usually Russian and/or German.

Finally, the question arises - how to improve the use of computers in teaching? Students feel that the best way for the elimination of all barriers is the existence of a large number of useful and practical courses and seminars on computers. Teachers need constant training, which would primarily work on breaking prejudices and fear of computer use, and in particular, the implementation of educational software in teaching, and afterward explained the purpose of the use of computers and the effects that may be achieved. If teachers were aware of benefits of computers to the efficiency of learning and cognitive activity of students, they probably would have tried to improve the teaching by this means.

To improve the use of computers in teaching we should increase the number of hardware (computers, printers, monitors, scanners) and software packages, as well as Internet connections. Access to the Internet at the Faculty of Education is possible only in computer classrooms. Increasing the number of Internet connections could be realzed by placing terminals in corridors, which would allow easy and quick access to all the small needs and quick email checking. One solution is the introduction of wireless connections for teachers and students, which makes sense considering the arrival of tablets, smartphones and other portable devices through which one can access the Internet. Be sure to work on improving English language skills for using the Internet and computers.

\section{Conclusion}

Availability of computers, fast flow of information and constant progress of communicationinformation technologies have led to many changes in all aspects of the modern society. Today, there is an expansion of computer applications in various aspects of scientific and technological progress. Following this trend, there are applications of computers in education, especially in teaching. Plenty of literature, educational software, the Internet, and e-learning are the main characteristics of modern education. 
The research, which was conducted among students, confirmed the positive opinion of students about the importance and using computers in teaching. Computers make it easier to prepare teaching materials, free from excessive exposure and providing more efficient teaching assistance. Using computers frees teachers from activities of technical and organizational nature. It can lead to higher methodological diversity in teaching and to shortening time for various preparatory activities.

With the presence of computers, teachers prepare exciting lectures for teaching materials.

Students react positively to the computer because its use leads to the refreshment of daily classes which can quickly become tiresome. They can consolidate their existing knowledge with greater motivation, but also adopt new knowledge quickly. Thanks to the computer, students can achieve better results than those achieved by traditional teaching. Positive effects of the use of computers and educational software in teaching activities were undisputed among students, but the use of the computer must be supported by a positive attitude of professors toward computers as teaching tools.

In general, teachers and students are mostly positive towards computers in their classrooms. The barriers to using computers in teaching are the lack of knowledge of the English language, the lack of hardware, software, and skills and time for creating course content. However, all of these barriers can be overcome with a little will and commitment. However, the general conclusion is that teachers are most adapted to existing conditions and rarely dare to change because they feel best in familiar forms and methods of teaching.

\section{References}

Alemu, B.M. (2015). Integrating ICT into teaching-learning practices: promise, challenges and future directions of higher educational institutes, Universal journal of educational research, 3(3), 170-189.

Brock, S. \& Joglekar, Y. (2011). Empowering PowerPoint: slides and teaching Effectiveness. Interdisciplinary journal of information, knowledge and management, 6, 86-94.

Ertmer, P. A. (1999). Addressing first- and second-order barriers to change: Strategies for technology integration. Educational technology research and development, 47(4), 47-61.

Ertmer, P.A., Ottenbreit-Leftwich, A. \& York, C.S. (2006-2007). Exemplary technology-using teachers: Perceptions of factors influencing success. Journal of computing in teacher education, 23(2),55-61.

Glušac, D. (2008). Elektronsko učenje. Zrenjanin, RS: Tehnički fakultet Mihajlo Pupin.

Hasselbring, T.S. \& Glaser, C. H.W. (2000). Use of computer technology to help students with special needs. The future of children - Childern and computer technology, 10(2), 102-122.

Inoue-Smith, Y. (2016). College-based case studies in using PowerPoint effectively, Cogent education, 3, 1-15.

Joy, J \& Srihari, M. (2015). Teachers' perception and attitude on ICT enabled education in leveraging academic atitude and professionalism, Research Journal of educational sciences, 3(10), 11-16.

Kafyulilo, A., Fisser, P., Pieters, J. \& Voogt, J. (2015). ICT use in science and mathematics teacher education in Tanzania: Developing technological pedagogical content knowledge, Australasian journal of educational technology, 31(4), 381-399.

Lucido, P.I. \& Borabo, M.L. (1997). Educational technology. Quezon City, PH: Katha Publishing Co., Inc.

MacGregor, R.R. (2007). The essential practices of high quality teaching and learning. Redmond, US: The Center for Educational Effectiveness, Inc.

Mandic, D. \& Ristic, M. (2006). Web portali i obrazovanje na daljinu u funkciji podizanja kvaliteta nastave, Beograd, RS: Merlin.

Marcial, D.E. \& Rama, P.A. (2015). ICT competency level of teacher education professionals in the Central Visayas Region, Philippines, Asia Pacific journal of multidisciplinary research, 3(5), 28-38.

Norris, L (2015). Learning to teach using ICT in the secondary school. A companion to school experience. Journal of interactive media in education, 1(11), 1-3.

Radenković, B. \& Ivković M. (1998). Internet i savremeno poslovanje. Zrenjanin:, RS: Tehnički fakultet Mihajlo Pupin.

Suzic, N. (2009). Naučna utemeljenost promjena u sistemu vaspitanja i obrazovanja. Naša škola, 3-4, 69-93.

Tall, D. (2000). Cognitive development in advanced mathematics using technology, Mathematics education research journal, 12(3), 196-218. 